Huibers, L., Smits, M., Christensen, M.B., Giesen, P., Wensing, M. Huisartsenposten in Nederland en Denemarken: een vergelijking. TSG: Tijdschrift voor

Gezondheidswetenschappen: 2017, 95(6), 254-257

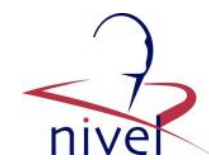

\begin{tabular}{|l|l|}
$\begin{array}{l}\text { Postprint } \\
\text { Version }\end{array}$ & 1.0 \\
\hline Journal website & https://link.springer.com/article/10.1007\%2Fs12508-017-0080-3 \\
\cline { 2 - 2 } Pubmed link & $10.1007 \% 2 F s 12508-017-0080-3$
\end{tabular}

This is a NIVEL certified Post Print, more info at http://www.nivel.eu

\title{
Huisartsenposten in Nederland en Denemarken: een vergelijking
}

\author{
Linda Huibers · MARLEEn SMits · MORTEn Bondo Christensen · GRETE Moth · PAUL \\ GIESEN
}

\section{INLEIDING}

Toen in Nederland rond het jaar 2000 de huisartsenzorg buiten kantoortijd werd gereorganiseerd, keek men ter inspiratie naar Denemarken, een land met een vergelijkbaar gezondheidszorgsysteem. Daar vond al in 1992 een eerste reorganisatie plaats van kleine waarneemgroepen naar grootschalige huisartsenposten [1]. Anno 2017 is het interessant om opnieuw te kijken hoe het er in Denemarken voor staat. Kunnen we in Nederland nog steeds geïnspireerd raken? Of zijn wij nu een voorbeeld voor Denemarken? In dit artikel kijken we eerst kort in hoeverre het gezondheidszorgsysteem van Denemarken en Nederland op elkaar lijken. Vervolgens vergelijken we de huisartsenzorg buiten kantoortijd, waarbij we zullen pogen te duiden wat de betekenis van de verschillen voor de kwaliteit van zorg is.

\section{KENMERKEN VAN DE GEZONDHEIDSZORGSYSTEMEN}

Denemarken en Nederland zijn moderne welvaartstaten met een redelijk gelijk sociaal en politiek klimaat, en met dezelfde onderliggende waarden, zoals vrije en gelijke toegang tot de gezondheidszorg. In beide landen is de huisarts de poortwachter van de gezondheidszorg, die zonder financiële drempel voor patiënten kan worden geconsulteerd [1-3]. Ook staan de landen voor dezelfde uitdagingen: hoge zorgvraag en uitgaven voor preventie en behandeling, veel laagurgente hulpvragen in de acute zorg en steeds zwaardere kwaliteitseisen $[2,4,5]$. Er zijn echter ook verschillen. De bevolkingsdichtheid in Nederland is drie keer zo groot als die in Denemarken (17,0 miljoen versus 5,7 miljoen inwoners op een vergelijkbare oppervlakte). In Denemarken worden veel sociale enmedische voorzieningen bekostigd uit belastinggeld en betaalt men geen verzekeringspremie. Het aantal patiënten in een normpraktijk is in Denemarken lager (Denemarken 1.600; Nederland 2.168). Deense huisartsen dragen de zorg voor zwangeren en de preventieve zorg voor kinderen, maar in Nederland hebben huisartsen hier geen of een minimale rol bij. Deense huisartsen doen de volledige ouderenzorg, omdat er geen verpleeghuisartsen zijn, terwijl in Nederland huisartsen alleen zorg dragen voor de thuiswonende ouderen. 
Huibers, L., Smits, M., Christensen, M.B., Giesen, P., Wensing, M. Huisartsenposten in Nederland en Denemarken: een vergelijking. TSG: Tijdschrift voor

Gezondheidswetenschappen: 2017, 95(6), 254-257

\section{HUISARTSENZORG BUITEN KANTOORTIJD}

De huisartsenzorg buiten kantoortijd wordt in beide landen geleverd in grootschalige organisaties met gebruik van telefonische triage, maar er zijn enkele opvallende verschillen. We vergelijken de huisartsenposten op het gebied van organisatiestructuur, inrichting van triage, uitrusting bij visites, motivatie van huisartsen, honoreringssysteem en zorggebruik door patiënten.

\section{[TABEL 1]}

\section{Organisatie}

In Denemarken zijn de regionale overheden verantwoordelijk voor de organisatie van de huisartsenzorg.

In vier van de vijf regio's is de organisatie van de zorg buiten kantoortijd op vergelijkbare wijze geregeld en in handen van de huisartsen zelf. De regio Kopenhagen heeft echter sinds januari 2014 een afwijkend model [1]. 'Acuuttelefoon 1813 ' is daar nu de uniforme toegang tot de zorg buiten kantoortijd (huisarts en tweede lijn). Verpleegkundigen beantwoorden de telefoon met hulp van een triagesysteem en kunnen zo nodig doorschakelen naar een (huis)arts. Deze artsen hoeven de telefonische contacten van de triagisten niet achteraf te fiatteren en zijn niet verantwoordelijk voor de triage. Na telefonische triage kan een consult (in het ziekenhuis) of visite volgen.

In de overige regio's organiseren de Deense huisartsen de zorg buiten kantoortijd op regionaal niveau met één toegangsnummer voor een adherentiegebied van circa 600.000 tot 1.300.000 inwoners (zie tab. 1).

Wel zijn ermeerdere callcenters en consultatieruimtes (ofwel posten), omdat de gebieden geografisch groot zijn. Zo hoeven huisartsen en patiënten niet zo ver te reizen. Ter vergelijking, in Nederland zijn er circa 120 huisartsenposten met 100.000 tot 500.000 inwoners per post [6-8].

In beide landen vormen de huisartsen de basis van de huisartsenpostorganisatie. In Nederland wordt de huisartsenpost meestal bestuurd door huisartsen, maar zijn de directie en dagelijkse leiding in handen van niet-huisartsen, aangevuld met een medisch adviseur.

De dagelijkse leiding is verantwoordelijk voor de triagisten, kwaliteitsontwikkeling en contracten voor chauffeurs en visiteauto's. De organisatie van de Deense huisartsenpost in de vier regio's ligt volledig bij de huisartsen zelf. Zij hebben huisartsen die als dienstchef diensten plannen en coördineren (gekozen en betaald door de huisartsen) en een beperkt secretariaat voor administratieve taken. Bij iedere dienst heeft één huisarts een coördinerende taak.

In het Deense model zonder vast personeel houden huisartsenwerkgroepen zich bezig met kwaliteitsontwikkeling.

\section{Triage}

In Denemarken wordt telefonische triage grotendeels verricht door huisartsen zelf, zonder beslissingsondersteunend triagesysteem. Het inzetten van een huisarts lijkt efficiënt, aangezien bijna $60 \%$ van alle contacten telefonisch afgehandeld wordt, in vergelijking met circa $40 \%$ via triage door doktersassistentes in Nederland [6,9]. Deense consult- en visiteartsen geven aan dat slechts een klein deel (ongeveer 12\%) van deze face-to-face contacten ook telefonisch afgehandeld had kunnen worden [9]. In Nederland bleek dat ongeveer $22 \%$ van de consulten vervangbaar was door een 
telefonisch consult van de huisarts [10]. Onduidelijk is of het aantal vervolgcontacten met de eigen huisarts of huisartsenpost verschilt. Kiest de huisarts aan de telefoon vaker voor afwachten of rondt hij een hulpvraag juist eerder af met een definitief advies of behandeling? In Nederland gebruiken triagisten een beslissingsondersteunend triagesysteem: de NHG-Triagewijzer of de computergestuurde variant daarvan, de Nederlandse Triage Standaard (NTS). Mogelijk draagt dit triagesysteembij aan het verschil. Een triagesysteem zorgt voor meer veiligheid, maar waarschijnlijk ook tot meer face-to-face contacten. Over veiligheid van triage zijn echter geen eenduidige conclusies te trekken: huisartsen hebben meer medische kennis, maar triagisten in Nederland gebruiken een onderbouwd triagesysteem en hebben een telefoonarts als back-up. De kwaliteit van de triagegesprekken wordt met regelmaat gecontroleerd en triagisten moeten daarbij aan bepaalde normen blijven voldoen voor herregistratie. De achtergrond van de triageprofessional leidt tot andere keuzen bij het zekeren van veiligheid. Daarnaast is de keuze van wie de triage uitvoert ook afhankelijk van de beschikbaarheid van professionals; niet ieder land heeft doktersassistentes, of voldoende verpleegkundigen beschikbaar.

\section{Visites}

In Denemarken worden visites gereden in een taxi met beperkte hulpmiddelen. De chauffeur heeft een korte eerstehulpcursus gehad om de huisarts te kunnen ondersteunen.

Visites in Nederland worden gereden in goed uitgeruste dienstauto's (met zuurstof, automatische externe defibrillator en medicatie), bestuurd door getrainde chauffeurs die ook opgeleid zijn om medische assistentie te verrichten. Dit verschil heeft ook te maken met het inzetten van visites: Deense huisartsen rijden geen spoedvisites; bij spoedeisende (en levensbedreigende) situaties wordt de ambulancehulpverlening ingeschakeld. Men kan eventueel ook een auto met huisarts sturen voor de eerste opvang en zo nodig rijdt de huisarts met de ambulance mee. Nederlandse huisartsen onderhouden hun ervaring met spoedeisende hulpvragen, maar de vraag is of er voldoende spoedeisende hulpvragen zijn om vaardigheden daadwerkelijk up-to-date te houden en bij een toename van ambulance-inzet bij triage dreigt deze expertise verder aangetast te worden.

\section{Motivatie en honorering van huisartsen}

Iedere Deense huisarts behoort dienst te doen, waarbij het aantal diensten in een regio gelijk verdeeld wordt onder de huisartsen, die diensten kunnen ruilen of weggeven. De motivatie van Deense huisartsen neemt echter af. In Nederland zijn huisartsen om hun registratie te behouden verplicht minimaal 50 uur per jaar dienst te doen. Van de Nederlandse huisartsen besteedt $84 \%$ geen tot maximaal een kwart van de diensten uit [11]. In beide landen zijn er ook jonge huisartsen en huisartsen zonder praktijk die alleen als waarnemer op de post werken.

De honorering voor diensten verschilt wezenlijk.

Nederlandse huisartsen worden per uur betaald, ongeacht diensttype en werkdruk. Deense huisartsen krijgen per contact betaald, met de hoogste honorering voor een visite. Ook is in Denemarken de vergoeding voor telefonische consulten relatief hoger vergeleken met telefonische contacten met een vervolgconsult of -visite, vanwege de langere duur. De hogere vergoeding voor een telefonisch consult 
Huibers, L., Smits, M., Christensen, M.B., Giesen, P., Wensing, M. Huisartsenposten in Nederland en Denemarken: een vergelijking. TSG: Tijdschrift voor

Gezondheidswetenschappen: 2017, 95(6), 254-257

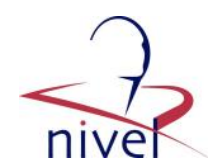

stimuleert het telefonisch afhandelen van een probleem. Het is onduidelijk wat het effect is op de patiënttevredenheid.

\section{Zorgconsumptie}

Zowel in Nederland als Denemarken is er veel discussie over de drukte op de huisartsenpost, vooral wat betreft het aantal niet-urgente klachten. In vergelijking met Denemarken lijkt de drukte echter mee te vallen.

Het aantal contacten met de huisartsenpost is met vijfhonderd contacten per duizend patiënten per jaar in Denemarken twee keer zo groot als in Nederland (250 contacten per duizend inwoners per jaar) $[6-8,12,13]$. Desondanks is er geen hoger gebruik van de spoedeisende hulp en/of dagzorg in Nederland. Het kan verleidelijk zijn te concluderen dat Deense huisartsen een hoge zorgconsumptie stimuleren, omdat zij worden betaald per verrichting en mogelijk minder geneigd zijn patiënten 'op te voeden', maar onderzoek hiernaar ontbreekt. Ook de directe toegang tot een huisarts aan de telefoon kan bijdragen aan een hogere consumptie, zeker omdat Deense huisartsenpraktijken in de namiddag alleen via de spoedlijn bereikbaar zijn. Het verschil kan ook veroorzaakt worden door verschillen in toegankelijkheid van de huisartsenpraktijk en huisartsenpost (maar in beide landen staat de bereikbaarheid van de eigen huisarts ter discussie) en in hulpzoekgedrag van Deense en Nederlandse burgers. De 24/7-consumptiemaatschappij speelt in beide landen mogelijk een rol bij het relatief hoge aantal niet-urgente klachten. Het hoge serviceniveau van het directe telefonische contact met een huisarts kan ook een verklaring vormen. Verder kan de grotere betrokkenheid van de Deense huisarts bij de preventieve zorg (consultatie en zwangeren) de verwachtingen van de burger beïnvloeden, waardoor zij mogelijk eerder aan de huisarts denken.

\section{BESCHOUWING}

Het Deense model van huisartsenposten was rond het jaar 2000 een voorbeeld voor Nederland. Op het gebied van triage hebben de Denen nu in één regio triage door verpleegkundigen met gebruik van een triagesysteem en (huis)artsen als back-up. Dit lijkt op het Nederlandse triagemodel, maar in Nederland zijn het meestal doktersassistentes die de triage verrichten, onder verantwoordelijkheid van huisartsen.

Opvallende verschillen tussen het Nederlandse en het meest voorkomende Deense organisatiemodel worden gevonden op het gebied van triage, honorering, inzet bij spoedvisites en zorgconsumptie. De directe telefonische toegang tot een huisarts in Denemarken geeft mogelijk een hoge mate van telefonische afhandeling, maar zou ook kunnen bijdragen aan een hogere zorgconsumptie. Onduidelijk is het effect van het Deense honoreringssysteem, waarbij per contact wordt betaald. Het Deense model met huisartstriage staat onder druk door de afnemende motivatie.

Tegelijkertijd is de mogelijk defensieve triage in Nederland ook vaak onderwerp van discussie. Verder lijken Nederlandse huisartsen meer ervaring op te bouwen met spoedeisende hulpvragen: zij rijden spoedvisites in goed ingerichte visiteauto's. In beide landen is de druk op de huisartsenpost groot, al is het aantal contacten per duizend inwoners in Denemarken beduidend hoger.

Kortom, Nederland heeft zich de afgelopen vijftien jaar sterk ontwikkeld in de huisartsenzorg buiten kantoortijd, en andere landen, zoals Denemarken, kunnen nu op bepaalde aspecten leren van ons model met systematische kwaliteitsontwikkeling en kwaliteitsborging bij triage. Veel verschillen hebben met keuzen te maken, 
Huibers, L., Smits, M., Christensen, M.B., Giesen, P., Wensing, M. Huisartsenposten in Nederland en Denemarken: een vergelijking. TSG: Tijdschrift voor

Gezondheidswetenschappen: 2017, 95(6), 254-257

waarbij er vooralsnog geen bewijs is dat het ene model tot betere kwaliteit leidt dan het andere. Onderzoek is nodig om te helpen de organisatie te optimaliseren, maar beide modellen functioneren goed.

\section{LITERATUUR}

1. OlesenF, JolleysJV.Outofhoursservice: theDanishsolution examined.

BMJ.1994;309:1624-6.

2. GrolR,GiesenP,UdenCvan. After-hours care intheUnited Kingdom, Denmark, and the Netherlands: new models. HealthAff (Millwood). 2006;25:1733-7.

3. ChristensenMB,OlesenF.Outofhours serviceinDenmark: evaluationfiveyearsafter reform. BMJ.1998;316:1502-5.

4. Giesen $P$, Huibers L, Krol M. Huisartsenzorg in cijfers: patiëntcontacten op de huisartsenpost. Huisarts Wet. 2011;54:5-6.

5. SmitsM,LenosM,GiesenP.Zorgconsumptieophuisartsenposten. HuisartsWet. 2014;57:137.

6. InEen. 2016. https://ineen.nl/assets/files/ assets/uploads/170824_Benchmarkbulletin 2016

Huisartsenposten.pdf.Geraadpleegdop6september2017.

7. Giesen P, Smits M, Huibers L, et al. Quality of after-hours primary care in the Netherlands: a narrative review. Ann InternMed. 2011;155:108-13.

8. SmitsM,RuttenM,KeizerE, etal.Thedevelopmentandperformance of after-hours primary care in the Netherlands: anarrativereview. AnnInternMed. 2017;166:737-42.

9. Huibers L, Moth G, Carlsen A, et al. Telephone triage by GPs in out-of-hours primary care: a prospective observational study of efficiency and relevance. Br J Gen Pract. 2016;66:e667-73.

10. Mout $P$,Giesen $P H J, M u ̈ s k e n s ~ R$, et al. Meeste consulten op

HAPmedischnoodzakelijk.MedContact. 2014;69:1102-4.

11. SmitsM,KeizerE,HuibersL,etal. Ervaringenvanhuisartsen opdehuisartsenpost. HuisartsWet. 2012;55:102-5.

12. HuibersL,MothG,AndersenM, etal. Consumptioninoutof- hours health care: Danish double Dutch? Scand J Prim HealthCare. 2014;32:44-50.

13. Danmarks Statistik. 2017. http://www.statistikbanken.dk/statbank5a/default.asp?w=1920. Geraadpleegd op 28 augustus2017.

\section{TABEL}

Tabel 1 Kenmerken van de Deense en Nederlandse huisartsenposten

\begin{tabular}{|l|l|l|}
\hline Kenmerken & Denemarken & \multicolumn{1}{l}{ Nederland } \\
\hline Aantal huisartsen/post & $300-1.000$ & $50-700$ \\
\hline Aantal patiënten/post & $\begin{array}{l}590.000-1.290 .000 \\
\text { Regio Kopenhagen (1.790.000) heeft andere organisatievorm }\end{array}$ & $100.000-500.000$ \\
\hline Openingstijden & $16-8$ uur, weekenden en feestdagen & $17-8$ uur, weekenden en feestdagen \\
\hline Maximale afstand tot post & Maximaal 35 km & Maximaal $30 \mathrm{~km}$ \\
\hline Telefonische triage & $\begin{array}{l}\text { Huisartsen (4 regio's); verpleegkundigen en (huis)artsen } \\
\text { (1 regio) }\end{array}$ & $\begin{array}{l}\text { Doktersassistentes en verpleegkundigen, gesuperviseerd } \\
\text { door huisarts }\end{array}$ \\
\hline $\begin{array}{l}\text { Financiering van huisartsen- } \\
\text { zorg buiten kantoortijd }\end{array}$ & $\begin{array}{l}\text { Volledig betaald door de nationale belastinggefundeerde } \\
\text { ziektekostenverzekering (zonder premie), behalve medicatie }\end{array}$ & $\begin{array}{l}\text { Volledig vergoed door de eigen verzekering (waarvoor premie } \\
\text { betaald wordt), behalve medicatie en onderzoek (eigen risico) }\end{array}$ \\
\hline Drempel tot spoedzorg & Geen betaling voor huisartsenpost, spoedeisende hulp en 112 & $\begin{array}{l}\text { Geen betaling voor huisartsenpost - voor de spoedeisende } \\
\text { hulp en 112 geldt het eigen risico (385 euro) }\end{array}$ \\
\hline Honorarium huisartsen & Betaling per verrichting (bedrag verschilt voor type dienst) & Salaris per uur (65 euro) \\
\hline Herregistratie huisarts & Geen eisen & Minimum 50 uur dienst per jaar \\
\hline
\end{tabular}

